\title{
FEATURES OF FUTURISM PERFORMANCE ON THE EXAMPLE OF THE WORKS 'LUNA, LUSSURIA E VELOCITA' IN ILKHAM NAZAROV'S INTERPRETATION
}

\section{Rufat Piriev}

PhD Candidate; ORCID: 0000-0003-3039-1770; e-mail: rufetvokal@mail.ru

Baku Music Academy named after U. Hajibeyli, Baku, Azerbaijan

\section{Abstract}

The purpose of the study is to determine the vocal performance characteristics of the 'Luna, Lussuria e Velocita' work, written in the style of futurism in the interpretation of I. Nazarov, taking into account the peculiarities of the timbre of his voice. 'Luna, Lussuria e Velocita' is written in the futuristic style and is intended for bass/countertenor and electronic musical instruments. The purpose of the research is to determine the features of the vocal performance of the 'Luna, Lussuria e Velocita' work composed in the style of futurism, taking into account the features of I. Nazarov's voice timbre. The research methodology is based on the use of music analytical, historical and theoretical analysis methods. The analysis of vocal performance given in the research was carried out based on the note presented by the composer and the video material performed by I. Nazarov. At the same time, a number of scientific literature on futurism was referred to. The scientific novelty of the research is that the work of Italian composer S. Muscaritolo 'Luna, Lussuria e Velocita' was involved in the study for the first time. The work is designed for two registers (bass/countertenor) and is composed in the style of futurism, which characterizes its scientific novelty. The work uses non-traditional playing methods for bass and countertenor. In the research, the research of vocal performance methods used by I.Nazarov during the performance was carried out for the first time. Conclusions. I.Nazarov is the first and only singer in the history of Azerbaijani music culture with a countertenor voice and boundless vocal technique. Not only Azerbaijani but also European composers create works of various genres in accordance with the possibilities of his voice. These works are new due to their features and performance requirements. In 'Luna, Lussuria e Velocita' I. Nazarov showed himself as a singer with high technical capabilities, able to perfectly control both the baritone and countertenor sound timbre. The singer expanded the possibilities of performing the countertenor sound timbre, which gave rise to the assessment of the sound timbre from a new position.

Keywords: Ilham Nazarov; countertenor; baritone; vocal; performance features; futurism

\section{Introduction}

The traditional European academic vocal art has a special place in the history of Azerbaijani music culture with ancient and rich traditions. Although the art of academic 
vocal performance in Azerbaijan originated at the beginning of the last century, it has undergone great historical development in a short period of time and has given Azerbaijan musical culture a generation of outstanding vocalists. They, in turn, managed to form our academic school of vocal performance. Even today, the brightest representatives of this school are able to have their say in the world music arena. One of them is Ilham Nazarov, the Honored Artist of the Republic of Azerbaijan, the Presidential Fellow, the first and only countertenor in Azerbaijan music culture.

\section{Purpose of the article}

The main purpose of the research is to determine the features of I. Nazarov's vocal performance on the example of 'Luna, Lussuria e Velocita'. The fact that the work is composed in the style of futurism, intended for bass/countertenor, is one of the issues, that makes the work relevant to research.

\section{Recent research and publications analysis}

Along with the articles of V. Humbatov (2020), O. Ozel (2021), X. Asgerova (2020), Y. Kukhmazova (2020) and others about I. Nazarov, scientific works on the study of futurism in music were used in the presented research. At the same time, the articles of D. Lombardi (1981), C. Poggi (2009), J. R. Payton's (1976) were referred to here as well as many electronic resources.

\section{Main research material}

It is not only his timbre, wide vocal possibilities that make I. Nazarov unique in the Azerbaijani musical culture. One of the main reasons for this is the writing of works in accordance with the timbre of the performer. Of course, this practice has existed in the history of vocal performance since the beginning of the twentieth century. The fact that Azerbaijani famous composer U. Hajibeyli intended Koroglu's part from the opera 'Koroglu', the romances 'Without You' and 'Dear Beloved' for the People's Artist of the USSR Bulbul marked the beginning of a new tradition in our music. This tendency is further reflected in the work of I. Nazarov. Thus, Azerbaijani as well as European composers created works taking into account his timbre. Works for cantata, opera, romance, orchestra of various compositions and sound can be mentioned here (Abdullazade, 2020 , p. 119). Another important feature of these works is that they were composed for two registers, as well as for a separate countertenor sound timbre. The study also analyzed the possibilities of vocal performance performed by I. Nazarov in the futuristic style of the Italian composer Stefano Muscaritolo's 'Luna, Lussuria e Velocita' and identified the characteristics of his voice and the principles of interpretation of these works.

'Luna, Lussuria e Velocita' was written in 2016. The first performer was I. Nazarov. And it was performed for the first time at an exhibition in the Lamborghini car showroom (Nazarov, 2016). Although the performance of the work in the car is interesting at first glance, it should be noted that it is closely related to its essence, the style in which it is written. 'Luna, Lussuria e Velocita' is written for countertenor/bass and pre-recorded 
electronic musical instruments. The text of the music belongs to Ludovico Ariosto (1474-1533) and Filipo Tomazo Marinetti (1876-1944).

The word futurism means 'future' in Latin. Futurism was first reflected in painting and literature. For this trend, the abandonment of traditional rules, the use of new forms and means of expression can be considered as the main characteristic. Futurism first originated in Italy and later spread to the cultures of other European countries. The main feature of futurism is the placement of different sounds, especially machine effects. In short, imitation, analogy, and imitation play a key role in futurism.

At the same time, futurism in music can be seen as a radical renewal. In addition to bringing new means of expression, this trend opened up new technical possibilities in the performing arts, enriched the aesthetics of sound with different traditions, and characterized a new view of the musical texture.

In his article 'Futurism and musical notes', the Italian musicologist Daniela Lombardi highlighted the following six aspects of the fundamental laws of futurism (Lombardi, 1981, p. 44):

1. Noisy sound;

2. Micro intervals;

3. Improvisation;

4. Synchronization;

5. To have different disciplines - to take the form of a theatrical concept, so to combine the features of genres such as theatre and opera;

6. Mechanics - imitation of sounds belonging to different machine industries.

All these points are reflected in the work of S. Muscaritolo. The work uses noise and micro intervals, but also has a theatrical concept and is based on imitation. The interesting thing is that all this is obtained through a vocal part and is intended for two registers of sound (bass/countertenor). The use of the countertenor sound timbre in futurism (machine/mechanical music), usually associated with the music of the Baroque period, the works of G. F. Handel, A.Vivaldi, I. S. Bach, and others, is rightly noteworthy. This means that the countertenor sound timbre transcends boundaries and emerges from a new position of performance.

Naturally, the vocal part plays a leading role in the work. Since the vocal part has two registers, it is written on two lines of notes, bass and left key. The accompaniment part is played by electronic musical instruments and there is no note material. The escort party is mainly of a background feature and creates a sense of tonal support. Accompaniment is sometimes used car engine sounds. This principle continues until the end of the work. The vocal part is sung over a pre-recorded accompaniment part. The tempo here is Rubato.

'Luna, Lussuria e Velocita' is a technically complex work for the vocalist and reflects the following performance difficulties:

'Luna, Lussuria e Velocita's' preference for both small and large vocal techniques;

- require small dynamic nuances;

- construction of the work on passages with different figures moving up and down;

- alternate and continuous sounding of both registers;

- presence of a wide range of jumps;

- use of different nuances. 
'Luna, Lussuria e Velocita', first of all, we would like to note his great preference for improvisation. His improvisation is free and thematic. This point can be observed in any part of the work. At the same time, rubato is an important component of the singer's interpretation.

The singer's voice in the work has a very flexible effect. It switches from one tone of voice to another very easily. Despite the fact that the dynamic plan of the work varies between $p$-ff, the singer uses the dynamic nuance $p-f$ in order to create a balance between the two timbres. Another feature of Nazarov's interpretation is his ability to obtain contrast through registers. Below are some vocal performance analyzes on some parts of that work.

'Luna, Lussuria e Velocita' begins with a small introduction by the escort party. After a 25 second imitation of various motor sounds, the vocal part is included. The vocal part is first performed in the bass. I. Nazarov sounded that part in $p$ dynamic tones, in a soft form. The imitation of the car engine at the beginning of the work is then played in a vocal part.

We have mentioned above that futurism brings innovations to the texture of the vocal part, to vocal performance. Here we pay attention to the imitation of motor sound by sound performed by I. Nazarov. The performer created the same effect by gliding in the $p-f$ dynamic nuance towards the G-B sounds, as in the text of the note.

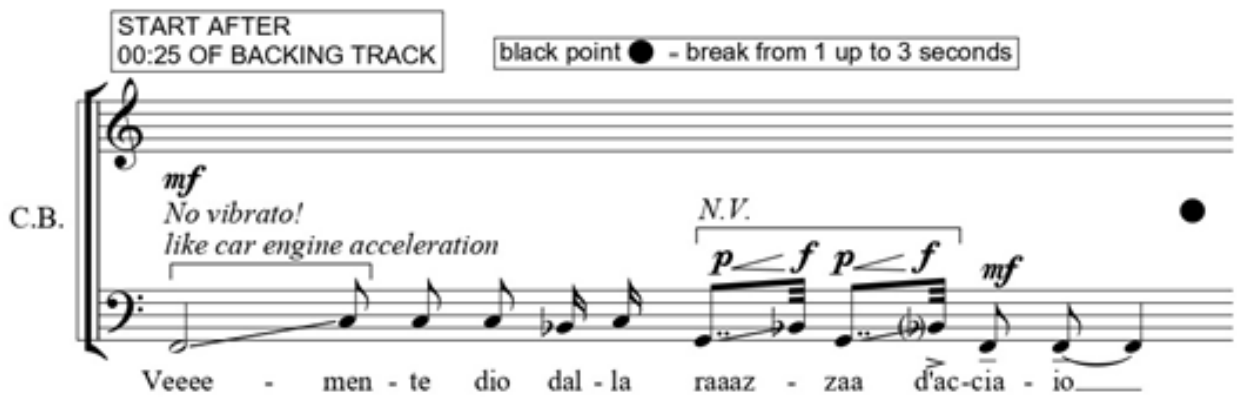

As mentioned above, one of the important difficulties in performing 'Luna, Lussuria e Velocita' is the alternation of timbres. Here the change of timbre is carried out in two forms:

1. After one sentence is played with the bass, the other sentence is played with a countertenor sound timbre;

2. Passing from one sound timbre to another during the performance of a musical sentence;

One of the difficulties in playing the presented part is the change of timbre by glissando from " $\mathrm{c}^{2 \text { " }}$ to the octave " $\mathrm{G}$ ". This is a point that requires a great deal of technical skill in vocal performance. As is well known, the vocal apparatus in both timbres is based on a different principle. This can be considered as a transition from one face to another. Changing the timbre on glissando is an indicator of I. Nazarov's unlimited sound capabilities.

In doing so, he switched from baritone to countertenor sound timbre. In this case, the character changes and the work is presented in a light form. If the baritone's loud 
timbre and the use of a chest register attracted attention during the performance, the passage is smooth from one sound to another. We would also like to note that this part falls on the singer's transitions.

One of the noteworthy points here is that despite the fact that the author marked the sentence 'Ebrra di Spazio' on a Flyjet, I. Nazarov sang it with a countertenor sound timbre. In this case, he takes advantage of the harsh sound and plays the word 'bra' with an accent. At the same time, the performer uses a diminuendo to the word 'di Spazio" and "di Spazio!' Near the end of the performance, the word almost disappears. After a short pause, the work continues in a baritone timbre. After a short pause, the work continues in a baritone timbre.

Let's pay attention to the performance features of the baritone part in 'Luna, Lussuria e Velocita'. In the phrase 'Che scalpiti che fremi d'angoscia, rodendo il mostro con strriduli denti', I. Nazarov used a hard sound, full voice, sound in $f$ dynamics, decisive performance style.
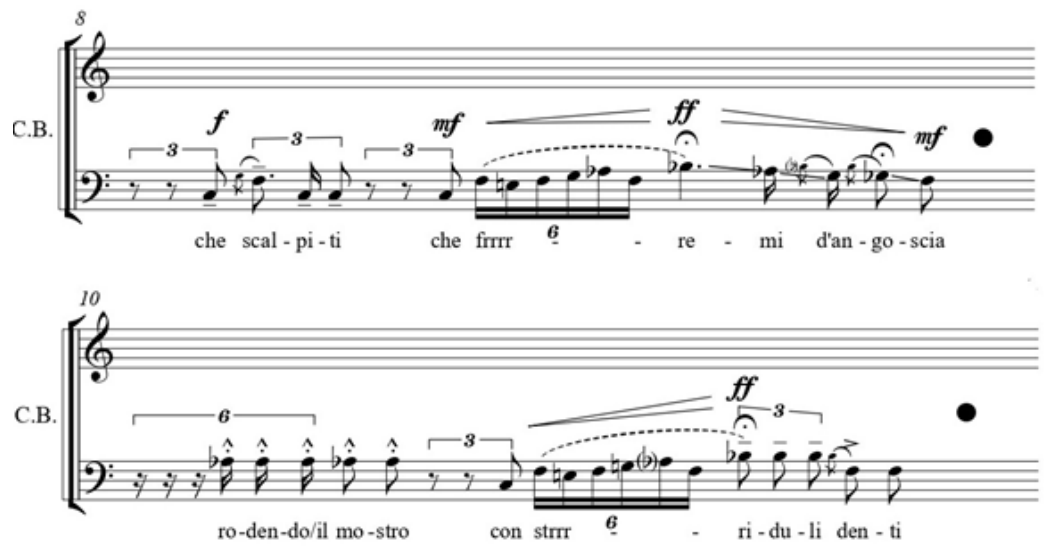

In the study, we noted that one of the characteristics of futuristic music is the use of micro-intervals and close tones in the work. In the example below, close intervals (especially bar 14) were also used.
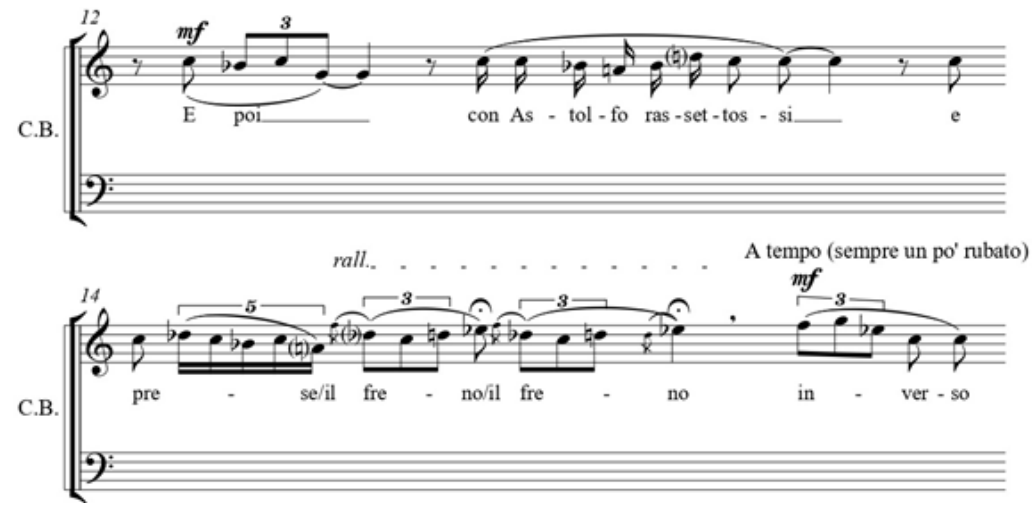
With this part, we would like to highlight the application of the Baroque sound timbre in futurism. Of course, when performing close intervals in atonal music in vocal performance, their performance requires such important qualities as precise hearing, absolute adjustment of the vocal apparatus at the time of performance, control. As is well known, the countertenor is a specific timbre. In other words, mainly Baroque music samples are designed for this timbre technique. For this reason, any work with any technical difficulties related to this period is very convenient for the countertenor. The performance of the work composed for the countertenor in the style of Futurism is a further improvement and expansion of the technical capabilities of this sound timbre, its field of application.

In the next part, I. Nazarov was able to demonstrate his technical capabilities at a high level in the countertenor, as well as baritone timbre. We would like to inform you that this part consists of passages.
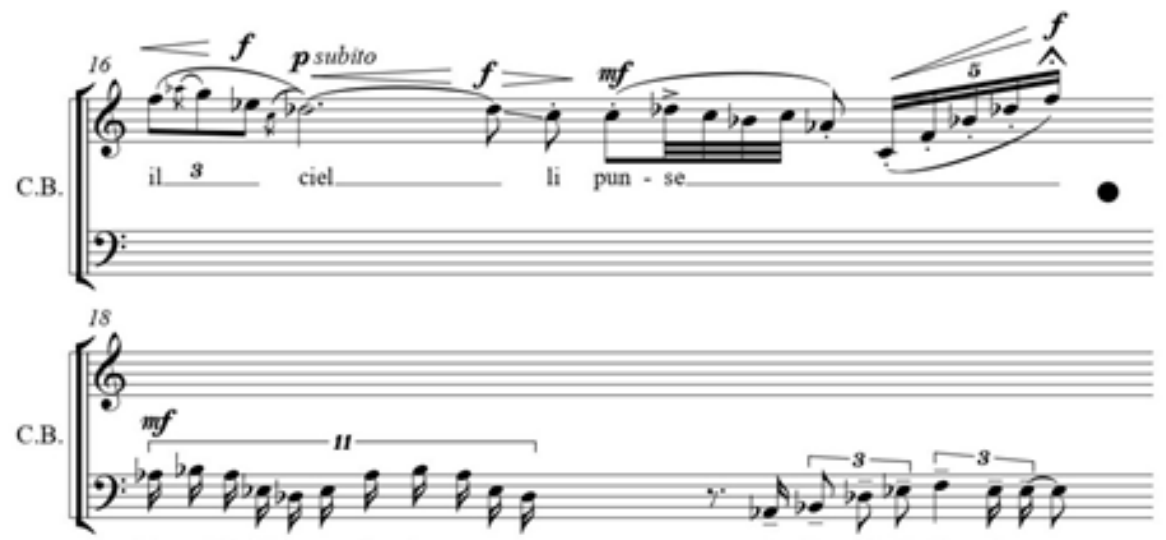

For-mi-da-bi-le mo-stro giap-po-ne-se da-gl'oc-chi di fu - ci-na_

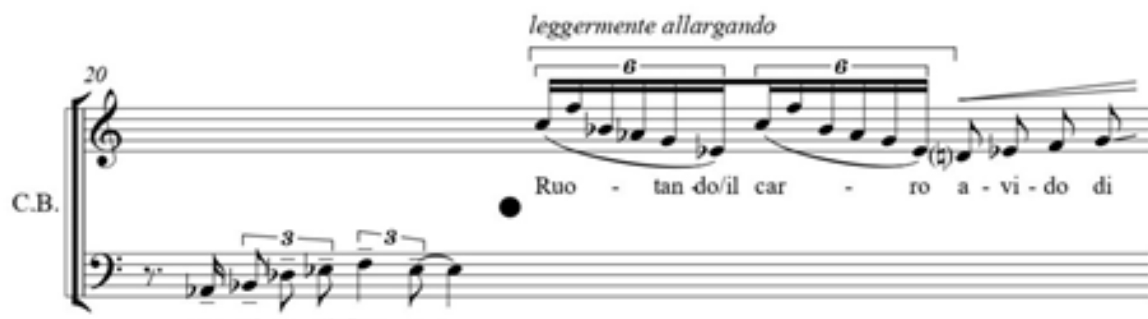
nu - tri - to di fiam- ma

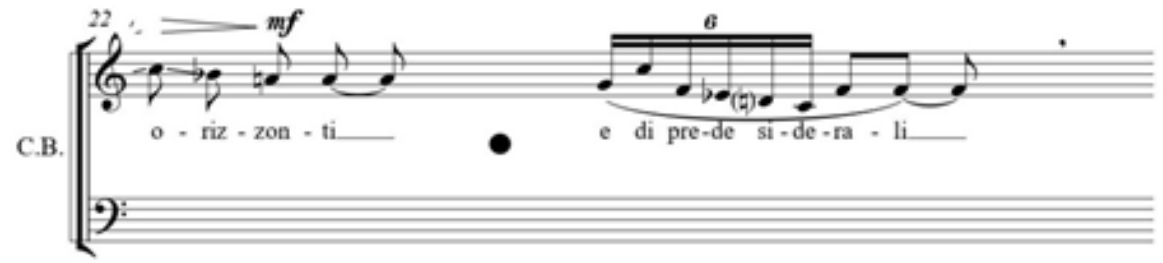

In both timbres, the downward and upward passages are performed in different nuances. Recording passages in both timbres on the outside of the register is also 
a performance challenge and requires the singer to pass from one timbre to another within a short period of time. It also makes it necessary to change the position of the vocal apparatus, the larynx every time, to use different breathing techniques. Another point of interest in this section is the use of various nuances and strokes.

The passage in the bass timbre ('Formidabile mostro giapponese da gl'occhi di fucina nutrito di fiamma') was performed very rubato. The singer's 'as-b-as' ('Formida') is based on the 'as' ('da') sound, while the 'es-des-es-a' ('formida BILE mostro') sound is relatively rallentando. 'B-as-es-des' ('giapponese'), here, in the expression 'giapponese', he pronounced 'Giap' with an accent and diminuendo near the end of the expression. When talking about the strokes used in this section, we can mention portamento and legato. We would also like to emphasize the use of speech intonation.

As for the passages performed by the countertenor, the same pattern of performance is not found in the interpretation. In this section, we would like to mention the variations and additions to the author's text. 'Ruotando il carro avido di orizzonti'; We see both in the sentences 'e di prede siderali'. It uses ornaments on the 32 notes in the sentence 'Ruotando il carro a'. Thus, in the passage ' $c^{1}-f^{2}-b^{1}-a s^{1}-g^{1}-e^{1}$ ('Ruotando il'), the performer created a stronghold by playing the word 'Ruo' (especially the pronunciation of the letter ' $r$ ') with an accent. Then the tempo was played slowly near the end of the passage. During the repetition of the passage, the sing er applied the previous model, emphasizing the word 'car'. Here, the performer also used mordent. The appendix applied by I. Nazarov to this part coincided with the end of the musical sentence beginning with the phrase 'e di prede siderali'. Here, the performer's forcible repetition of the ' $\mathrm{f}$ ' ' sound was done in order to create a more complete image.

The performer's voice is very light in the downward and upward gamma-ray passage, which begins with the phrase 'che mentre lo passar non era ardente.' The finale of I. Nazarov's work is interpreted in an interesting way. Thus, despite the completion of the work in the author's text, the performer improvises, and then the work ends in the dynamics of $\mathrm{p}$, with the intonation of speech, the whispering of the text.

\section{Conclusion}

Thus, as a result of the vocal performance analysis of S. Muscaritolo's 'Luna, Lussuria e Velocita' performed by I. Nazarov, the following conclusion was made:

- Here, the singer used different shades of colour. This is evident when playing with baritone and countertenor sounds.

- The musician used rich means of expression, portamento, legato, staccato, glissando and other nuances in the work.

- I. Nazarov presented the dramatic plan of the work in perfect form. Here, the beginning and end of the work are completed with the same sound, which leads to the artistic and content clarity of the work.

- Throughout the work, I. Nazarov proved to be a singer with high technical abilities capable of perfectly controlling both the baritone and countertenor sound timbre.

All the highlighted points gave grounds to note I. Nazarov's work as one of the first performers of futurism in Azerbaijan musical culture. 


\section{References}

Abdullazade, G. (2020). Ilham Nazarov: Serhedsiz Ses... [IIham Nazarov: A Boundless Voice...]. Savad [in Azerbaijani].

Asgerova, X. (2020). "Sarı Gelin" Xalq Mahnisi Ilham Nazarovun Tefsirinde [The Folk Song "Sari Gelin" in the Interpretation by Ilham Nazarov]. Medeniyyet/Culture, 5(333), 38-41 [in Azerbaijani].

Humbatov, V. (2020). Scientific Work of Ilham Nazarov, a Prominent Representative of the Modern Vocal Performance School of Azerbaijan. Bulletin of Kyiv National University of Culture and Arts. Series in Musical Art, 3(2), 132-145. https://doi.org/10.31866/26167581.3.2.2020.219158

Kukhmazova, Y. (2020). Azerbaycan Vokal Ifachiligi Kontekstinde Ilham Nazarovun Yaradiciliginin Novatorlug Khususiyyetlerine Dair [On the Innovative Features of the Creativity of Ilham Nazarov in the Context of Azerbaijani Vocal Performance Art]. Musiqi Elmi, Madaniyyati va Tahsilinin Actual Problemlari [Actual Problems of Music Science, Culture and Education], 1(8), 61-69 [in Azerbaijani].

Lombardi, D. (1981). Futurism and Musical Notes. Artforum, 19(5), 43-49.

Nazarov, I. (2016, June 27). Lomborghini... music [Video]. YouTube. https://www.youtube.com/ watch?v=3kRIDFmr3Uw

Ozel, O. (2021). Manifestation of Azerbaijani Music Elements in Ilham Nazarov's Performance Technique as a Countertenor. Bulletin of Kyiv National University of Culture and Arts. Series in Musical Art,4(1), 152-166. https://doi.org/10.31866/2616-7581.4.1.2021.233348

Payton, J. R. (1976). The Music of Futurism: Concerts and Polemics. The Musical Quaterly, 62(1), 25-45. https://doi.org/10.1093/mq/LXII.1.25

Poggi, C. (2009). The Futurist Noise Machine. The European Legacy, 14(7), 821-840. https://doi. org/10.1080/10848770903363912

\section{ОСОБЛИВОСТІ ВИКОНАННЯ ФУТУРИЗМУ НА ПРИКЛАДІ ТВОРУ «LUNA, LUSSURIA E VELOCITA» В ІНТЕРПРЕТАЦІЇ ІЛЬХАМА НАЗАРОВА}

\section{Руфат Пірієв}

дисертант; ORCID: 0000-0003-3039-1770; e-mail: rufetvokal@mail.ru

Бакинська музична академія мені Узеїра Гаджибейлі, Баку, Азербайджан

\section{Анотація}

Мета дослідження - визначити вокально-виконавські особливості творy «Luna, Lussuria e Velocita», написаного в стилі футуризму в інтерпретації І. Назарова з урахуванням особливостей тембру його голосу. Для реалізації цього завдання розглянуто особливості інтерпретації твору «Luna, Lussuria e Velocita», призначеного для баса / контртенора та електронних музичних інструментів у виконанні заслуженого артиста Азербайджанської Республіки І. Назарова. Методологія дослідження базується на використанні методів 
музично-аналітичного, історичного та теоретичного аналізу. Вокально-виконавський аналіз проведено на основі нот, представлених композитором і відеоматеріалу, відтвореного у виконанні І. Назарова. Водночас опрацьовано та узагальнено наукову літературу, предметом дослідження якої є футуризм. Наукова новизна дослідження. Твір італійського композитора C. Мускарітоло «Luna, Lussuria e Velocita» вперше залучено до проведеного дослідження. Те, що твір призначений для двох регістрів (бас / контртенор) і складений в стилі футуризму, характеризує його наукову новизну. У творі використані нетрадиційні для баса і контртенора техніки виконання. Також вперше було проведено дослідження вокальних методів, які використовував під час виконання І. Назаров. Висновки. І. Назаров - перший і єдиний в історії азербайджанської музичної культури співак, що володіє тембром контртенорового голосу, безмежною вокальною технікою виконання. Відповідно до можливостей тембру його голосу не тільки азербайджанські, а і європейські композитори складають твори, що охоплюють різні жанри. Такі твори нові за своїми особливостями, виконавськими вимогами. У творі «Luna, Lussuria e Velocita» I. Назаров показав себе співаком з високими технічними можливостями, здатним досконало опановувати як баритон, так і тембр контртенорового голосу.

Ключові слова: Ільхам Назаров; контртенор; баритон; вокал; виконавські особливості; «Luna, Lussuria e Velocita»; футуризм

\section{ОСОБЕННОСТИ ИСПОЛНЕНИЯ ФУТУРИЗМА HA ПРИМЕРЕ ПРОИЗВЕДЕНИЯ «LUNA, LUSSURIA E VELOCITA» В ИНТЕРПРЕТАЦИИ ИЛЬХАМА НАЗАРОВА}

\section{Руфат Пириев}

диссертант; ORCID: 0000-0003-3039-1770; e-mail: rufetvokal@mail.ru

Бакинская музыкальная академия имени Узеира Гаджибейли, Баку, Азербайджан

\section{Аннотация}

Цель исследования - определить вокально-исполнительские особенности произведения «Luna, Lussuria e Velocita», написанного в стиле футуризма в интерпретации И. Назарова с учетом особенностей тембра его голоса. Для реализации этой задачи рассмотрены особенности интерпретации произведения «Luna, Lussuria e Velocita», предназначенного для баса/контртенора и электронных музыкальных инструментов в исполнении заслуженного артиста Азербайджанской Республики И. Назарова. Методология исследования основана на использовании методов музыкальноаналитического, исторического и теоретического анализа. Вокально-исполнительский анализ проведен на основе нот, представленных композитором и видеоматериала, воспроизводимого в исполнении И. Назарова. В то же время была проработана и обобщена научная литература, предметом исследования которой является футуризм. Научная новизна исследования. Произведение итальянского композитора C. Мускаритоло «Luna, Lussuria e Velocita» впервые привлечено к проведенному исследованию. То, что произведение предназначено для двух регистров (бас/контртенор) и составлено в стиле футуризма, характеризует его научную новизну. В произведении 
использованы нетрадиционные для баса и контртенора техники исполнения. Также впервые было проведено исследование вокальных методов, используемых во время исполнения И. Назаровым. Выводы. И. Назаров - первый и единственный в истории азербайджанской музыкальной культуры певец, обладающий тембром контртенорового голоса, безграничной вокальной техникой исполнения. В соответствии с возможностями тембра его голоса не только азербайджанские, но и европейские композиторы сочиняют произведения, охватывающие различные жанры. Такие произведения новы по своим особенностям, исполнительским требованиям. В произведении «Luna, Lussuria e Velocita» И. Назаров показал себя певцом с высокими техническими возможностями, способным в совершенстве управлять как баритоном, так и тембром контртенорового голоса.

Ключевые слова: Ильхам Назаров; контртенор; баритон; вокал; исполнительские особенности; «Luna, Lussuria e Velocita»; футуризм 